\title{
Temperature, salinity and food effects on asexual reproduction and abundance of the scyphozoan Chrysaora quinquecirrha
}

\author{
Jennifer E. Purcell ${ }^{1, *}$, Jacques R. White ${ }^{1, * *}$, David A. Nemazie ${ }^{1}$, David A. Wright ${ }^{2}$ \\ ${ }^{1}$ University of Maryland Center for Environmental Science (UMCES), Horn Point Laboratory, PO Box 775, Cambridge, \\ Maryland 21613, USA \\ ${ }^{2}$ UMCES, Chesapeake Biological Laboratory, PO Box 38, Solomons, Maryland 20688-0038, USA
}

\begin{abstract}
Outbreaks of jellyfish are reported worldwide, yet the environmental factors that control the sizes of jellyfish populations are not well understood. The scyphomedusan Chrysaora quinquecirrha occurs in the mesohaline portion of Chesapeake Bay each summer. Population sizes of the medusae show dramatic annual variations that are correlated with salinity and temperature. We measured the total numbers of ephyrae and polyps produced by benthic polyps of $C$. quinquecirrha in laboratory experiments lasting $42 \mathrm{~d}$, and found that temperature $\left(15,20,25^{\circ} \mathrm{C}\right)$ was not a statistically significant factor at low salinities ( 5 to $20 \%$ ); however, ephyra production increased significantly with increasing temperature at high salinities $\left(20\right.$ to $35 \%$ ). Conversely, each $5^{\circ} \mathrm{C}$ decrease in temperature delayed strobilation (ephyra production) by about $1 \mathrm{wk}$. Salinity significantly affected the numbers of ephyrae and polyps produced in all experiments. Ephyra and polyp production was lower at both low (<11\%) and high salinities $(\geq 25 \%$ ) than at intermediate salinities. Also, more ephyrae, but not polyps, were produced with more available prey. Medusa numbers were 2 orders of magnitude lower in July 1996 when water temperatures, salinities, and zooplankton densities in Chesapeake Bay all were lower than in July 1995. The effects of these factors are important in understanding the changes caused by human activities in near-shore ecosystems, including effects of global warming, eutrophication, and reduction of commercial species
\end{abstract}

KEY WORDS: Cnidaria - Scyphozoa - Medusa - Scyphistoma - Temperature - Salinity - Zooplankton Production - Strobilation - Environmental factors - Asexual reproduction

\section{INTRODUCTION}

High biomasses of large jellyfish are noticed periodically in estuaries and partly enclosed marine waters worldwide (e.g. Yasuda 1970, Möller 1979, Cargo \& King 1990, Purcell et al. 1999). There has been considerable interest as to the causes and effects of conspicuous jellyfish outbreaks, because coastal areas are heavily used for human activities, and jellyfish cause concerns about potential human health hazards and

\footnotetext{
·E-mail: purcell@hpl.umces.edu

- Present address: People for Puget Sound, 1402 3rd Avenue, Suite 1200, Seattle, Washington 98101, USA
}

economic losses due to reduction of recreational activities and fisheries.

When jellyfish occur in large numbers, their predation can have substantial effects on the zooplankton and ichthyoplankton populations. Because the predominant summertime scyphomedusae in Chesapeake Bay, Chrysara quinquecirrha, are voracious consumers of zooplankton and ichthyoplankton (e.g. Purcell 1992, Cowan \& Houde 1993, Purcell et al. 1994a, b), they may be detrimental to estuarine fish populations. Food web analyses suggest that, due to their high trophic positions and high abundance, this gelatinous species is extremely important to plankton dynamics during the summer in Chesapeake Bay (Baird \& Ulanowicz 1989). 
The life cycles of coastal scyphomedusae include a benthic stage (scyphistoma) that lives attached to hard surfaces and a swimming stage, the medusa. Scyphistomae of Chrysaora quinquecirrha reproduce asexually in 2 ways; polyps can be formed by budding, and 1 to $2 \mathrm{~mm}$ medusae (ephyrae) are released by segmentation called strobilation (Cargo \& Rabenold 1980). The scyphistomae spend the cold winter months in a dormant state (cyst) and then excyst to form polyps, which produce ephyrae when spring water temperatures reach $17^{\circ} \mathrm{C}$ (Cargo \& Schultz 1967). Ephyrae are budded from scyphistomae mostly in June, but continue through September (Calder 1974). The medusa stage becomes sexually reproductive at about $2 \mathrm{~cm}$ diameter (Purcell unpubl. data). Planula larvae from fertilized eggs settle to become the benthic scyphistomae. The medusae die in the autumn, probably in response to falling water temperatures (Gatz et al. 1973), but the scyphistomae may survive for more than 1 yr (Cargo \& Schultz 1967).

Population size of the swimming medusa stage in any given year is determined by the abundance of scyphistomae, the production of ephyrae, and survival of the ephyrae. Only the studies of Hernroth \& Gröndahl (1983, 1985) and Gröndahl \& Hernroth (1987) examine environmental factors in situ (temperature, light, and a nudibranch predator of the polyps) that may affect ephyra abundance. Numerous factors (temperature, light, iodide and thyroxine, bacterial exudates, and the presence of zooxanthellae) have been found in laboratory experiments to initiate strobilation in several species of scyphomedusae (Spangenberg 1967, 1968, Loeb 1972, Hofmann et al. 1978, 1996). For Chrysaora quinquecirrha in Chesapeake Bay, strobilation occurs in spring when 3 environmental factors (light, temperature, and food) are increasing, and salinity is decreasing, so it is difficult to distinguish which factors are most important in situ. Loeb (1972) concluded that several weeks of chilling ('pre-conditioning') and subsequent warming of the polyps by about $6^{\circ} \mathrm{C}$ was necessary for strobilation.

Some cnidarians occur in low salinity waters, but species diversity decreases sharply with decreased salinity (Dumont 1994). Chrysaora quinquecirrha is unusual among cnidarians because it tolerates salinities as low as $5 \%$ and thrives at salinities of 10 to $12 \%$. The scyphistomae are not found in Chesapeake Bay where salimities are less than $7 \%$, and thrive at salinities of 10 to $25 \%$; surprisingly, the polyps are not found in bay waters above 25\% (Cargo \& Schultz 1966, 1967). Thus, the populations of $C$. quinquecirrha in the mesohaline portion of Chesapeake Bay may be limited by both low $(<5 \%)$ and high $(>25 \%)$ salinities, which is intriguing in terms of their ecology and their physiology (see Wright \& Purcell 1997).
Salinity decreases throughout the spring in Chesapeake Bay (Calder 1974. Cargo \& King 1990), but the effect of salinity on strobilation in Chrysara quinquecirrha is unknown. Salinity has not been identified as a likely trigger for strobilation in other scyphomedusae (Spangenberg 1968, Hernroth \& Gröndahl 1985); however, salinity and iodide concentrations are linearly correlated (Luther \& Cole 1988), and iodide is required for strobilation by scyphistomae, which synthesize thyroxine and related compounds (Spangenberg 1967, 1968, 1971, Black \& Webb 1973, Silverstone et al. 1978). Both Aurelia aurita and $C$. quinquecirrha showed increased strobilation with increasing iodide concentrations (1 to $100 \mathrm{mM}$, Spangenberg 1967, and 300 to $600 \mathrm{nM}$, Black \& Webb 1973). Threshold concentrations of iodide necessary to stimulate strobilation were not determined. Iodine concentrations in Chesapeake Bay ranged from $470 \mathrm{nM}$ at $35 \%$ to $70 \mathrm{nM}$ at $5 \%$ (Luther \& Cole 1988). Iodide concentration was $200 \mathrm{nM}$ in a tributary of Chesapeake Bay where salinity was 19 to $21 \%$ (Black \& Webb 1973). Therefore, nanomolar levels of iodide sufficient to stimulate strobilation in C. quinquecirrha are present in mesohaline tributary waters of Chesapeake Bay.

There has been speculation that eutrophication of coastal waters has lead to increased populations of jellyfish (Parsons et al. 1977). The abundance of food is undoubtedly an important factor in determining the population sizes of medusae. Thiel (1962) first showed the effects of food concentration on strobilation in Aurelia aurita. The number of segments on scyphistomae increased with increased food (Spangenberg 1967,1968 ). The greatest numbers of segments in $A$. aurita strobilae in situ occurred in autumn after the peak zooplankton biomass (Hernroth \& Gröndahl 1983). Chen et al. (1985) showed increased strobilation with increased food in Rhopilema esculenta in the laboratory

Here we report laboratory experiments to test the effects of temperature, salinity, and food levels on the production of Chrysaora quinquecirrha ephyrae and polyps. Dramatic differences in the numbers and distributions of medusae in Chesapeake Bay in July 1995 and 1996 are discussed relative to differences in temperature, salinity, and zooplankton densities.

\section{METHODS AND MATERIALS}

Laboratory experiments. Oyster shells with polyps of Chrysaora quinquecirha were collected with a dredge during April 1991 and 1992, from a tributary of the Choptank River, where water temperature was $13^{\circ} \mathrm{C}$ and salinity was $11 \%$, and transported to the 
Horn Point Laboratory on the Choptank River, a tributary of Chesapeake Bay in Maryland. At the time of collection, polyps had experienced the natural seasonal environmental conditions, which included several weeks of chilling, which is required before strobilation will occur (Loeb 1972). The oyster shells with polyps were maintained in $20 \mathrm{l}$ buckets of aerated estuary water in an environmental chamber at $12{ }^{\circ} \mathrm{C}$ and $20 \%$ before the experiments. Polyps were fed Artemia salina nauplii and water was replaced every 3 to $4 \mathrm{~d}$. No strobilation occurred under those conditions.

Treatment water used in the experiments was collected from Indian River inlet, Delaware (32\%), and the salinity increased by adding Instant Ocean sea salt, or decreased by mixing with deionized water. All water was filtered before use in experiments with a combination of glass fiber pre-filters and $0.22 \mu \mathrm{m}$ Nucleopore brand MF filters.

Three separate experiments were conducted to examine the combined effects of temperature and salinity on ephyra and polyp production. Each experiment comprised a matrix of different temperature and salinity combinations, with each condition having 4 replicate dishes. Expt 1 (June to July 1991) was designed to examine the combined effects of temperatures typical of spring and summer $\left(15,20,25^{\circ} \mathrm{C}\right)$, and salinities characteristic of oligo- to mesohaline regions of Chesapeake Bay (5, 10, 15, 20\%). Expt 2 (September to October 1991) was run at 1 temperature $\left(25^{\circ} \mathrm{C}\right)$ to specifically determine the minimum salinity $(5,7,9$, $11 \%$ ) necessary for ephyra production. Expt 3 (July to August 1992) tested the combined effects of temperature $\left(15,20,25^{\circ} \mathrm{C}\right)$ and moderate to high salinities $(20$, $25,30,35 \%$ ) characteristic of lower-bay and ocean waters.

Polyps were prepared for experimental treatments by cutting the oyster shells into sections bearing 3 to 16 polyps each. This method subjected the polyps to less stress than removal from the shell. The shell pieces were cleaned of other attached organisms, affixed to the bottom of plastic $375 \mathrm{ml}$ petri dishes with either natural bees wax or non-toxic modeling clay, and covered with $200 \mathrm{ml}$ of treatment solution. The polyps were acclimated to experimental salinities and temperatures by changing both parameters simultaneously over increments of $5^{\circ} \mathrm{C}$ and $5 \%$ daily until experimental conditions were attained. The treatments were maintained at experimental temperatures in walk-in incubators with dim fluorescent lights on a 12 h light : $12 \mathrm{~h}$ dark cycle. The numbers of living polyps and ephyrae were counted daily, and water in the dishes replaced and uneaten zooplankton removed every other day. All experiments were run for $42 d$.
The polyps were fed 3 or 4 times per week in all experiments; however, the foods offered to polyps differed among experiments. Expt 1 was the low food treatment, in which polyps were fed only cultured copepod nauplii (Acartia tonsa). Prey densities were estimated by counting subsamples using a dissecting microscope. In Expt 2, polyps were fed a combination of Artemia salina nauplii and copepod nauplii. Expt 3 was the high food treatment, in which polyps were fed mixed natural zooplankton that passed through a $200 \mu \mathrm{m}$ Nitex mesh. The concentration of zooplankton in the petri dishes was measured with a Coulter particle counter.

The raw data (total ephyrae and total polyps produced) from each experiment were tested for deviations from normal distributions before statistical analysis. All data sets required logarithmic transformation. The log transformed data were analyzed in a completely factorial design analysis of variance (ANOVA) procedure. The hypothesis that treatments within an experiment were significantly different $(p<0.05)$ was satisfied in all experiments except for polyp production in Expt 3.

Field sampling. Sampling was conducted as part of the NSF sponsored LMER (Land Margin Ecosystem Research) project in Chesapeake Bay called TIES (Trophic Interactions in Estuarine Systems). Bay wide sampling occurred during 19 to 29 July 1995 and 16 to 26 July 1996. Temperature and salinity were measured with a CTD at 30 to 40 stations during each cruise. At each station, zooplankton and jellyfish samples were collected with a $1 \mathrm{~m}^{2}$ Tucker Trawl fitted with $280 \mu \mathrm{m}$ mesh nets and a General Oceanics flowmeter. Samples from oblique hauls from the pycnocline to the surface were poured through a collander that retained Chrysaora quinquecirrha medusae, which were rinsed and counted. Zooplankton from those samples were preserved in ethanol. In 1996, no medusae were caught in the Tucker Trawl, so we counted medusae from a midwater trawl, with a nominal mouth area of $8 \mathrm{~m}^{2}$ and a cod end mesh size of $6 \mathrm{~mm}$, which was towed obliquely from bottom to surface for $20 \mathrm{~min}$. Densities of medusae were estimated using the calculated volume of water filtered during these trawls, which was approximately $38000 \mathrm{~m}^{3}$, based on net mouth size, ship speed, and tow duration. In 1995, zooplankton were counted (by use of a dissecting microscope) from 3 subsamples taken with a $5 \mathrm{ml}$ Hensen stempel pipette from each of the Tucker Trawl samples, which were brought to $2 \mathrm{l}$ volume and agitated before subsampling. In 1996, zooplankton were counted in the same manner from samples taken at $1 \mathrm{~m}$ depth with a diaphragm pump, which ran for 5 min at $20 \mathrm{lmin}^{-1}$, filtered through a $200 \mu \mathrm{m}$ sieve, and preserved. 

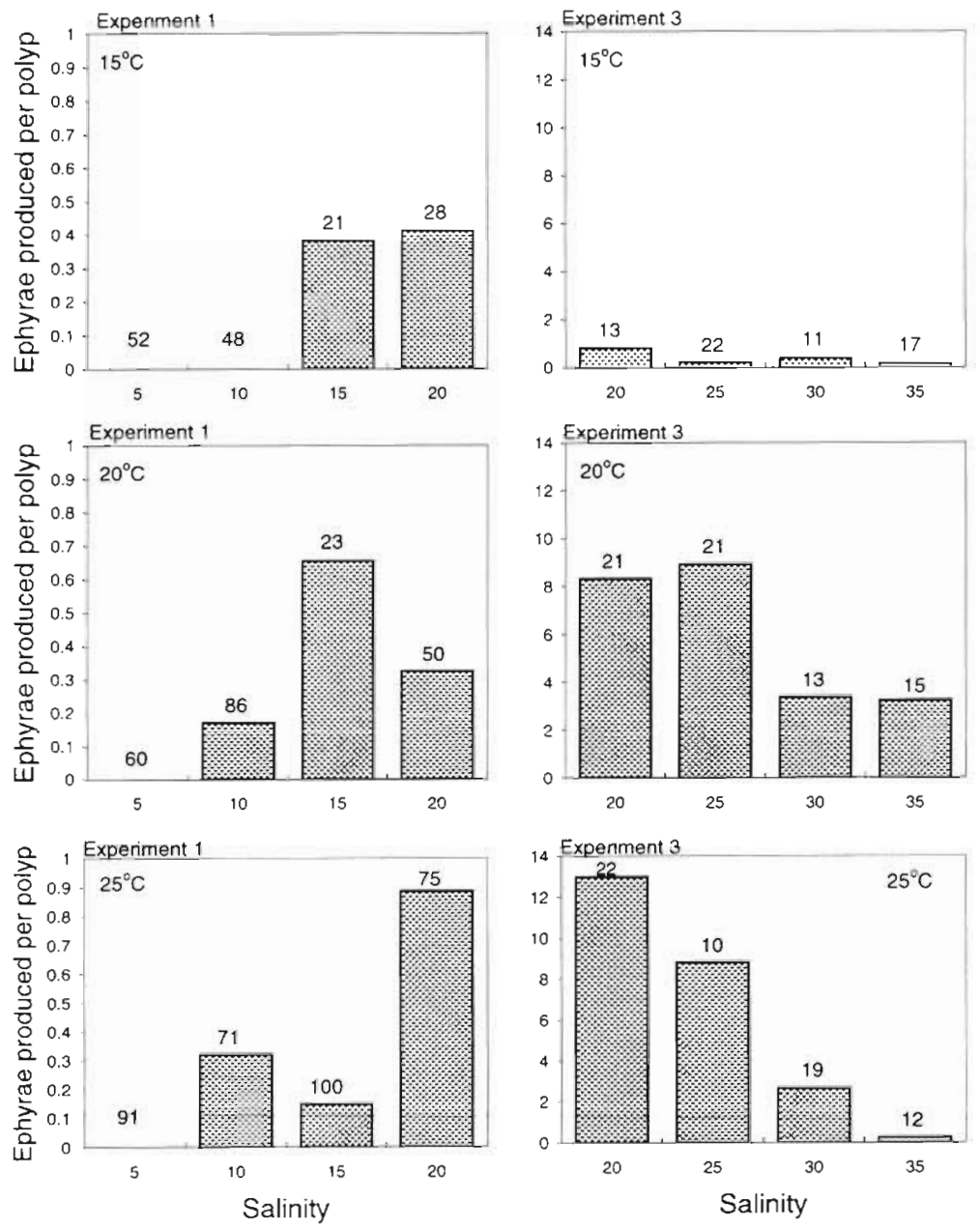

Fig. 1. Chrysaora quinquecirrha. Total numbers of ephyrae produced per polyp (initial numbers) in Expt 1 (5 to 20\%) and in Expt 3 (20 to $35 \%)$ at 3 temperatures $\left(15,20\right.$, and $\left.25^{\circ} \mathrm{C}\right)$ during $42 \mathrm{~d}$. Initial numbers of polyps are given above each bar

at the high temperature $\left(25^{\circ} \mathrm{C}\right)$, about $1 \mathrm{wk}$ later at $20^{\circ} \mathrm{C}$, and another week later at $15^{\circ} \mathrm{C}$ in both Expts 1 and 3 (Fig, 3). There was no apparent effect of temperature on production of new polyps (Figs. 4 \& 5), and temperature effects were not significant (Table 1).

\section{Effects of salinity}

Ephyra production was maximum at 20\% in Expts 1 and 3, showing reduced strobilation at both lower and higher salinities (Figs. 1 \& 2). No ephyrae were produced at $5 \%$ in any experiment (Figs. 1, 2 $\& 6)$. The lowest salinities in which substantial strobilation occurred were 10 to $11 \%$ in Expts 1 and 2, respectively (Figs. 1, $2 \& 6$ ). Similarly, new polyp production was low at salinities below $10 \%$ and above $20 \%$ (Figs. 4, $5 \& 6$ ). Effects of salinity on ephyra and polyp production were significant in all experiments (Table 1).

\section{RESULTS}

\section{Laboratory experiments}

Effects of temperature

There were fewer ephyrae produced per polyp at $15^{\circ} \mathrm{C}$ in both Expts 1 and 3 (Figs. 1 \& 2), although temperature was a significant factor only in Expt 3 (Table 1). The main effect of temperature was in the onset of strobilation, which occurred first

Fig. 2. Chrysaora quinquecirsha. Same data as in Fig. 1 (total numbers of ephyrae produced per polyp), but with all temperatures combined $\left(15,20,25^{\circ} \mathrm{C}\right)$, and all salinities combined, in Expt 1 (5 to 20\%) and in Expt 3 (20 to $35 \%$ ). Initial numbers of polyps are given above each bar
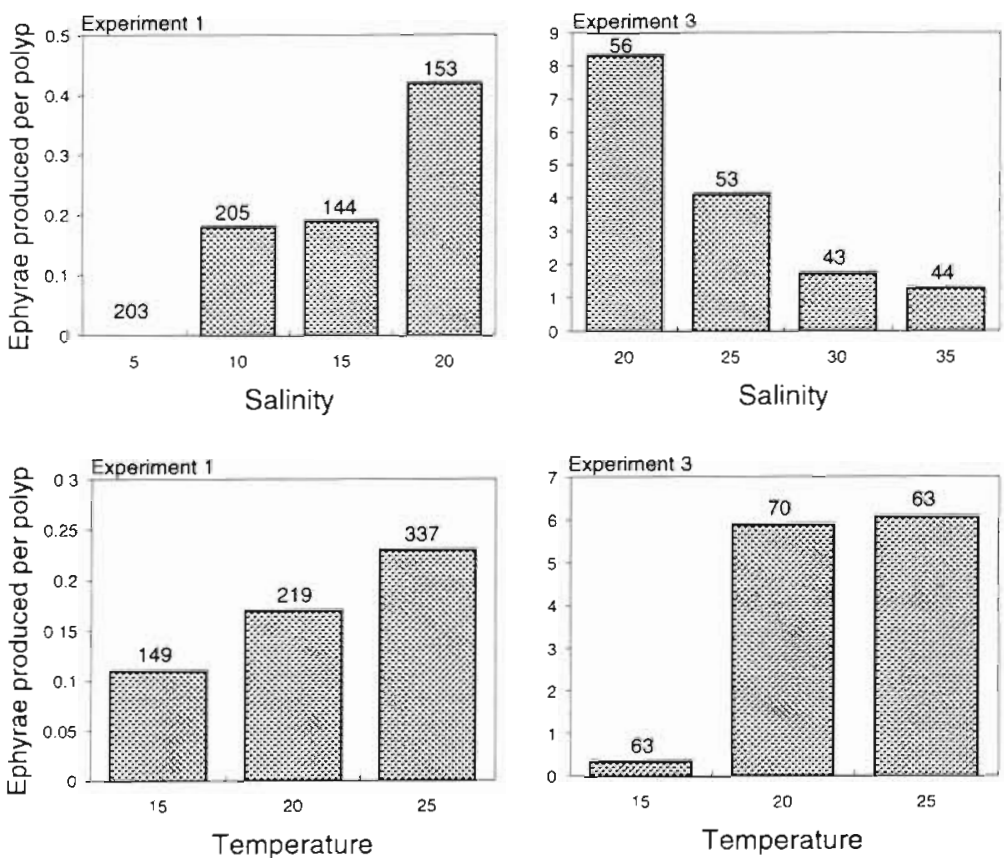
Table 1. List of experiment conditions, variables, effects, F-ratios and $\mathrm{p}$ values from Factorial ANOVA. Experiment = overall effects; SAL = effects of salinity; TEMP = effects of temperature; and SAL TEMP = interaction between salinity and temperature

\begin{tabular}{|c|c|c|c|c|c|}
\hline $\begin{array}{l}\text { Experiment/ } \\
\text { conditions }\end{array}$ & Variable & Effect & $\mathrm{df}$ & F-ratio & $\mathrm{p}$ \\
\hline \multirow{8}{*}{$\begin{array}{l}\text { 1. } 5-20 \% \\
15-25^{\circ} \mathrm{C}\end{array}$} & \multirow[t]{4}{*}{ Ephyrae } & Experiment & 12 & 7.515 & $<0.001$ \\
\hline & & SAL & 3 & 7.718 & $<0.001$ \\
\hline & & TEMP & 2 & 0.693 & 0.507 \\
\hline & & SAL TEMP & 6 & 2.027 & 0.087 \\
\hline & \multirow[t]{4}{*}{ Polyps } & Experiment & 12. & 4.302 & $<0.001$ \\
\hline & & SAL & 3 & 6.048 & 0.002 \\
\hline & & TEMP & 2 & 2.463 & 0.100 \\
\hline & & SAL TEMP & 6 & 0.929 & 0.487 \\
\hline \multirow{4}{*}{$\begin{array}{l}\text { 2. } 5-11 \% \circ \\
25^{\circ} \mathrm{C}\end{array}$} & \multirow[t]{2}{*}{ Ephyrae } & Experiment & 4 & 4.461 & 0.022 \\
\hline & & SAL & 3 & 4.236 & 0.032 \\
\hline & \multirow[t]{2}{*}{ Polyps } & Experiment & 4 & 5.132 & 0.014 \\
\hline & & SAL & 3 & 4.359 & 0.030 \\
\hline \multirow{8}{*}{$\begin{array}{l}\text { 3. } 20-35 \% \\
15-25^{\circ} \mathrm{C}\end{array}$} & \multirow[t]{4}{*}{ Ephyrae } & Experiment & 12 & 6.169 & 0.002 \\
\hline & & SAL & 3 & 5.518 & 0.013 \\
\hline & & TEMP & 2 & 10.624 & 0.002 \\
\hline & & $\mathrm{SAL} \cdot \mathrm{TEMP}$ & 6 & 1.116 & 0.409 \\
\hline & \multirow[t]{4}{*}{ Polyps } & Experiment & 12 & 2.018 & 0.119 \\
\hline & & $\mathrm{SAL}$ & 3 & 4.012 & 0.034 \\
\hline & & TEMP & 2 & 1.932 & 0.187 \\
\hline & & SAL 'TEMP & 6 & 0.600 & 0.726 \\
\hline
\end{tabular}

Effects of food

The effects of food were tested by comparing ephyra and polyp production at $20 \%$ in Expts 1 and 3 . In Expt 1, the polyps were given only cultured copepod nauplii (0.2 prey $\mathrm{ml}^{-1}$ ), which yielded a low rate of ephyra production (0.3 to 0.9 ephyrae polyp ${ }^{-1}$ ) (Figs. 1 \& 2). In Expt 3, the polyps were fed with natural zooplankton $\leq 200 \mu \mathrm{m}$ (4.3 to 4.4 prey $\mathrm{ml}^{-1}$ ), and ephyra production was high ( 1 to 13 ephyrae polyp ${ }^{-1}$ ) (Figs. 1 $\& 2)$. In contrast, similar numbers of new polyps were produced in both experiments $(0.7$ to 1.7 polyps polyp $^{-1}$ in Expt 1, and 0.5 to 0.9 in Expt 3) (Figs. 4 \& 5) Statistical comparisions between Expts 1 and 3 showed that ephyra production differed significantly between food treatments (ANOVA, p $<0.001$ ), but that new polyp production did not differ significantly with food level

\section{Field sampling}

Salinity, temperature, and zooplankton and medusa densities were measured in the surface layer of Chesapeake Bay in July 1995 and 1996 (Table 2). Freshwater inputs to the bay were about $25 \%$ below the long-term average in 1995, but about $25 \%$ above the average in 1996 (Boynton et al. 1997). This resulted in markedly lower salinities (about $2 \%$ baywide) in July 1996 than in 1995, and water temperatures also were lower (about $2^{\circ} \mathrm{C}$ baywide) in July 1996 than in 1995. Zooplankton densities also were lower in July 1996 than in 1995. At stations where Chrysaora quinquecirrha medusae were found in the Tucker Trawl samples, medusa densities ranged from 1 to 9 per $100 \mathrm{~m}^{3}$ in 1995; however, no specimens were collected in identical sampling in July 1996. Medusa densities estimated from midwater trawl sampling in 1996 were 2 orders of magnitude lower $\left(0.01\right.$ to 0.04 per $\left.100 \mathrm{~m}^{3}\right)$ than in 1995. Also, the distributions of medusae were different in the 2 years, with medusae being mainly north of the Potomoc River in 1995, but mainly south of the Potomoc River in 1996 (Fig. 7). The stations where medusae were collected differed in temperature (about $3.5^{\circ} \mathrm{C}$ ) and zooplankton densities (about 2 -fold) between years, but did not differ in salinity (Table 2), because the medusa population was shifted south towards the bay mouth where salinities were higher.
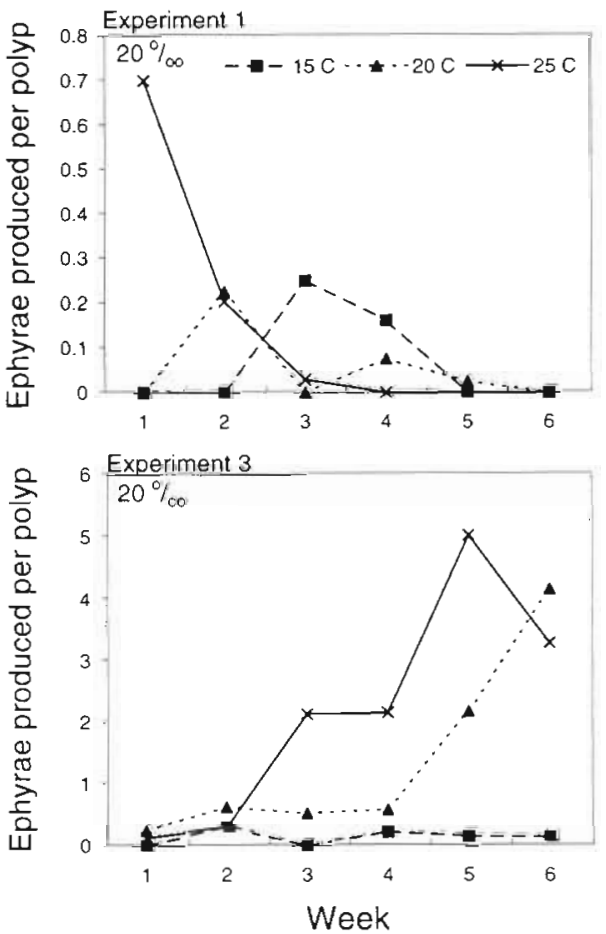

Fig. 3. Chrysaora quinquecirrha. Weekly totals of the numbers of ephyrae produced per polyp (initial numbers) in Expt 1 and in Expt 3 at $20 \%$ salinity for 3 different temperatures $\left(15,20\right.$, and $\left.25^{\circ} \mathrm{C}\right)$ 

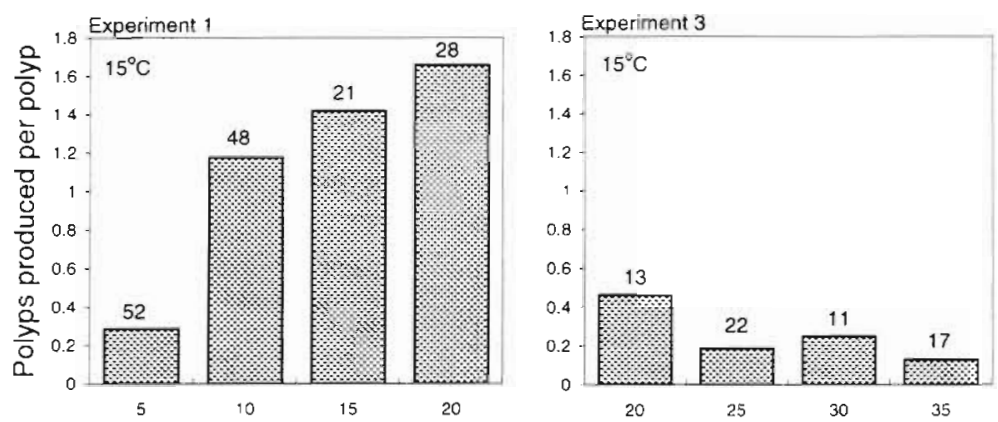

Fig. 4. Chrysaora quinquecirrha. Total numbers of polyps produced per polyp (initial numbers) in Expt 1 (5 to 20\%) and in Expt 3 (20 to $35 \%$ ) at 3 temperatures $\left(15,20\right.$, and $\left.25^{\circ} \mathrm{C}\right)$ during $42 \mathrm{~d}$. Initial numbers of polyps are given above each bar
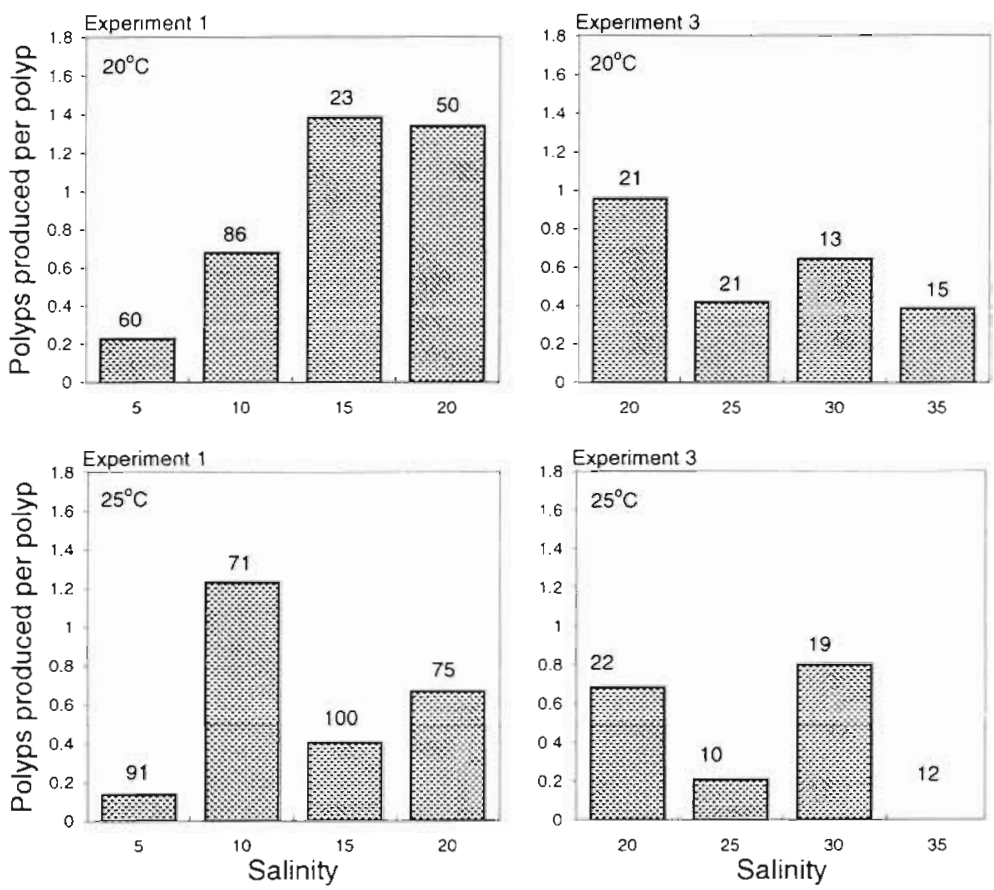

$15^{\circ} \mathrm{C}$, which is below the initiation temperature reported previously by Cargo \& Schultz (1967), Cones \& Haven (1969), and Calder (1974). Temperature did affect the timing of strobilation in our experiments; each $5^{\circ} \mathrm{C}$ reduction in temperature delayed peak production by about $1 \mathrm{wk}$. Cool environmental temperatures also delay the appearance of $C$. quinquecirrha medusae in Chesapeake Bay (Cargo \& King 1990).

Changing temperatures may be the stimulus that initiates strobilation for most scyphomedusan species, including Chrysaora quinquecirha, Cyanea capillata, and Cotylorhiza tuberculata (Cargo \& Schultz 1967, Calder 1974, Gröndahl \& Hernroth 1987, Brewer \& Feingold 1991, Kikinger 1992). However, for Aurelia aurita, Hernroth \& Gröndahl (1985) believed that temperature change did not trigger strobilation because spring warming only occurred in the surface layer above the

\section{DISCUSSION}

\section{Laboratory experiments}

Effects of temperature

In the low salinity (5 to $20 \%$ ) experiments, temperature did not significantly affect the total numbers of Chrysaora quinquecirrha ephyrae or polyps produced. Strobilation occurred even at

Fig. 5. Chrysaora quinquecirrha. Same data as in Fig. 4 (total numbers of polyps produced per polyp\}, but with all temperatures combined $\left(15,20,25^{\circ} \mathrm{C}\right)$, and all salinities combined, in Expt 1 (5 to $20 \%$ ) and in Expt $3(20$ to $35 \%$ ). Initial numbers of polyps are given above each bar
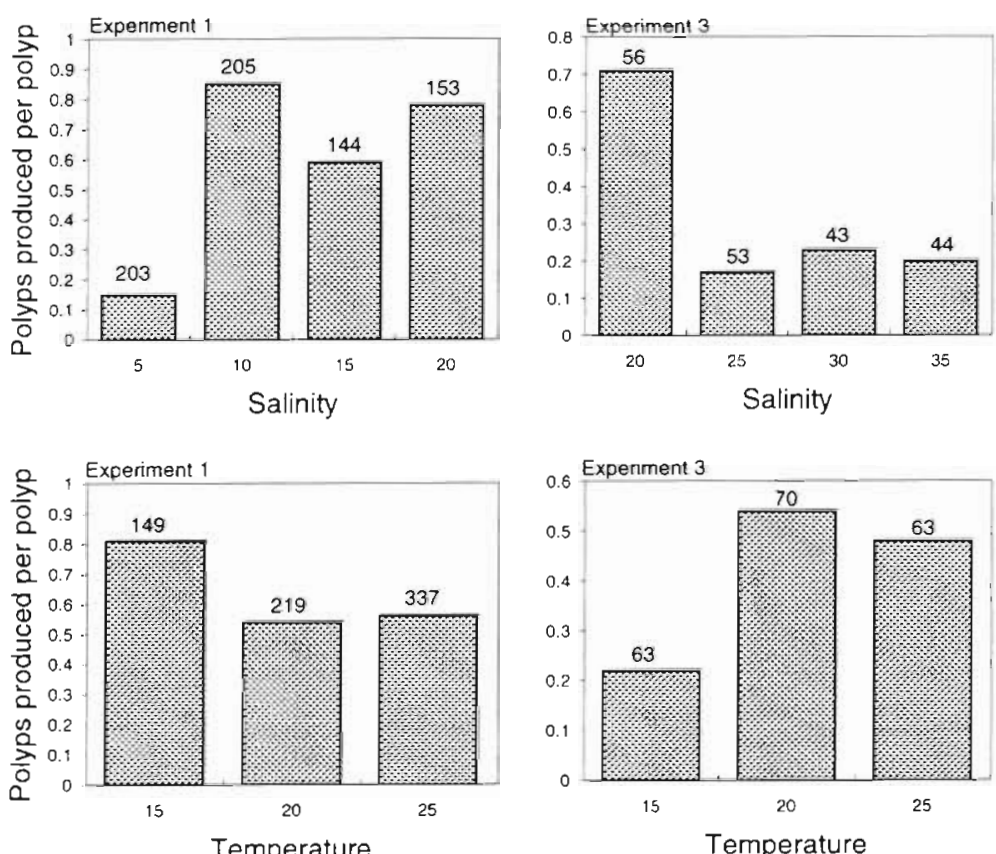

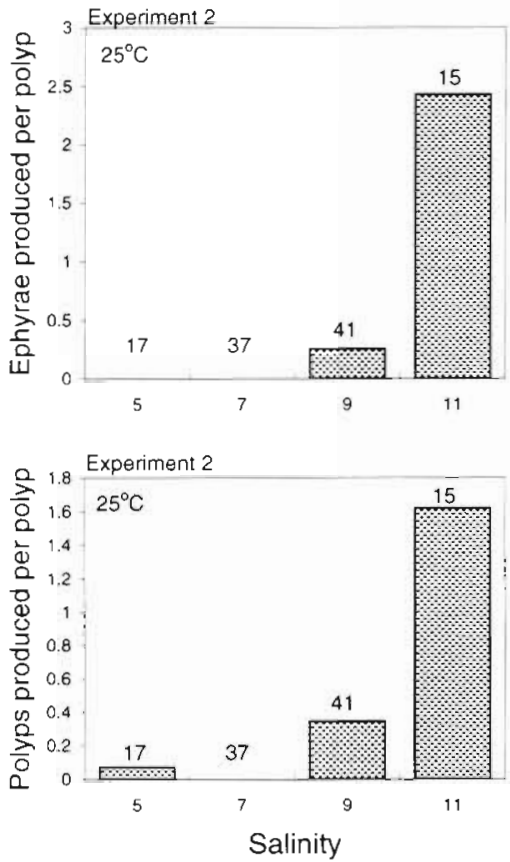

Fig. 6. Chrysaora quinquecirrha. Total numbers of ephyrae (top) and polyps (bottom) produced per polyp (initial numbers) in Expt $2(5$ to $11 \%$ ) during $42 \mathrm{~d}$. Initial numbers of polyps are given above each bar

polyps, and strobilating polyps occurred in autumn through spring. Seasonal salinity changes were $<2 \%$ and were thought unlikely to be the trigger. Therefore, they concluded that changing light conditions must be the stimulus triggering strobilation. The effects of light on strobilation have been studied only for $A$. aurita, and those experimental results are not definitive (reviewed in Spangenberg 1968). Light conditions were consistent throughout all of our experiments and could not be responsible for any of the observed differences.

\section{Effects of salinity}

The results of the production experiments were consistent with field observations that medusae and polyps are found in waters of $\geq 7 \%$ and $\leq 25 \%$ salinities (Cargo \& Schultz 1966, 1967). Specifically, our experiments showed that both ephyra and polyp production were low at salinities of 5,30 , and $35 \%$. Salinity, or a co-varying factor such as iodine, can affect medusa population size by affecting the numbers of ephyrae and polyps produced. Asexual reproduction abruptly declined at salinities $<10 \%$.
Whether the higher strobilation at salinities $>10 \%$ relative to that at salinities $<10 \%$ is directly related to salinity or corresponding iodide levels is not known. Luther \& Cole (1988) showed that iodide concentration was directly related to salinity; in our experiments, iodide would have ranged from $67 \mathrm{nM}$ at $5 \%$ salinity to $470 \mathrm{nM}$ at $35 \%$ salinity. Scyphistomae of Chrysara quinquecirrha accumulated iodide against a concentration gradient (Black \& Webb 1973), and the rate of accumulation increased with increasing temperatures (Olmon \& Webb 1974). Our results on ephyra production at low salinities (Expts 1 and 2) are consistent with the idea that increasing iodide availability and accumulation by the scyphistomae would increase strobilation, with a threshold occurring at about $10 \%$ salinity (200 nM iodide). The fact that production of both polyps and ephyrae of C. quinquecirrha was low at low salinities suggests that ionic regulation may be compromised at low salinities (Wright \& Purcell 1997). Low salinities might be expected to be stressful to $C$. quinquecirrha because few cnidarian species inhabit oligohaline waters (Dumont 1994).

More surprising is the low production of Chrysara quinquecirrha ephyrae and polyps at high salinities (25 to $35 \%$ ), to which most cnidarian species are adapted. Cones \& Haven (1969) stated that ephyrae were not produced at 35 and $40 \%$ and that the polyps encysted above $35.5 \%$. Polyps were absent from areas where salinities were 19 to $25 \%$, and they encysted or died in experiments run at 25,30, and $35 \%$ (Cargo \& Schultz 1966). Our results (Expt 3) showed that few ephyrae and polyps were produced at salinities above $20 \%$. Because high iodide concentrations would occur at these high salinities, which should have stimulated higher strobilation (Black \& Webb 1973), iodide probably was not responsible for the reduced asexual reproduction of $C$. quinquecirrha at high salinities.

The observed low asexual reproduction at high salinities by Chrysaora quinquecirrha polyps from Chesapeake Bay is puzzling because this species also occurs in high salinity coastal waters along the U.S. Atlantic and Gulf Coasts (Mayer 1910, Kramp 1961).

Table 2. Environmental parameters at stations where Chrysaora quinquecirrha medusae were collected in July 1995 and 1996. TT = Tucker Trawl samples; $\mathrm{MT}=$ midwater trawl samples. Numbers are means $\pm 1 \mathrm{SD}$

\begin{tabular}{|lcc|}
\hline Variable & 1995 & 1996 \\
\hline No. of stations with medusae & 18 of $46 \mathrm{TT}$ & O of $30 \mathrm{TT}, 17$ of $30 \mathrm{MT}$ \\
Range $\left({ }^{\circ} \mathrm{N}\right.$ latitude) & 37.5 to 39.00 & 37.33 to 38.67 \\
Temperature $\left({ }^{\circ} \mathrm{C}\right)$ & $29.1 \pm 0.4$ & $25.5 \pm 1.14$ \\
Salinity (\%o) & $14.1 \pm 1.7$ & $14.4 \pm 5.3$ \\
Zooplankton (no. $\left.\mathrm{m}^{-3}\right)$ & $2251.8 \pm 2027.4$ & $875.7 \pm 626.4$ \\
\hline
\end{tabular}




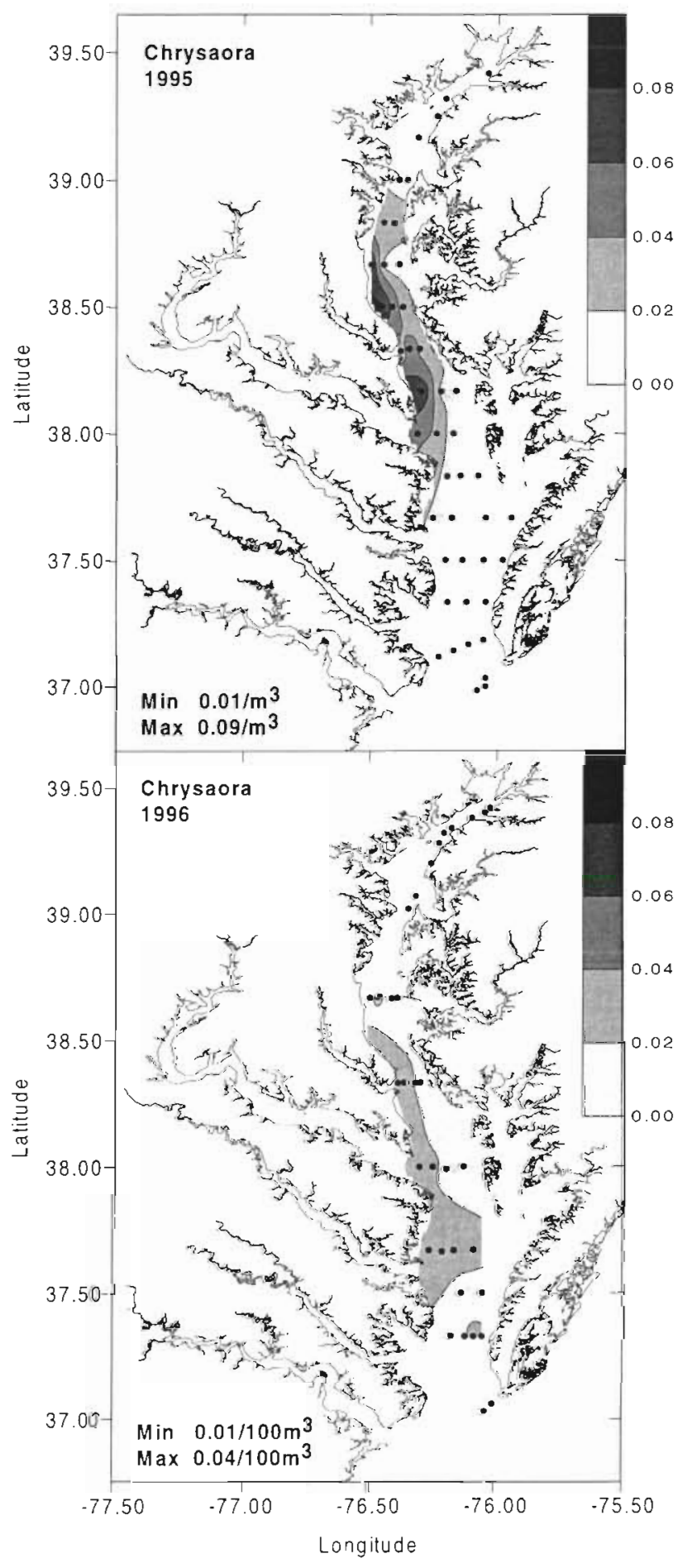

Fig. 7. Chrysaora quinquecirrha. Densities of medusae in Chesapeake Bay in July 1995 (numbers $\mathrm{m}^{-3}$ ) and 1996 (numbers $\left.100 \mathrm{~m}^{-3}\right) \cdot(\bullet)$ Stations sampled

C. quinquecirrha medusae from those waters are marked with reddish brown stripes on the swimming bell and down the oral arms (Mayer 1910), unlike medusae from the mesohaline Chesapeake Bay, which are milky white without dark pigmentation. Thus, we conclude that there is a local population adapted to the mid-salinity range found in the mesohaline portion of Chesapeake Bay. Whether this 'mid-salinity' (white) form is genetically distinct from the 'high-salinity' (red) form has not been determined; however, both red and white medusae were found in 10 of 17 trawl samples in July 1996. Presumably, the red medusae are carried up the bay in high salinity bottom waters, and the white medusae are carried down the bay in the low salinity surface layer, which is the typical summertime circulation pattern in Chesapeake Bay.

\section{Effects of food}

In our experiments, ephyra production was greatly increased when polyps were provided with more food. Increased prey abundance in situ could cause a rapid increase in the population size of medusae. Numbers of ephyrae similar to those in the high food treatment (1 to 13) were produced per polyp in situ (Calder 1974). By contrast, we saw no increase in polyp numbers with increased food availability. Polyp production would not be as rapid a response to trophic conditions as ephyra production. Therefore, asexual production of polyps may be a long-term strategy to maintain populations, and ephyra production may be more flexible, enabling the population to respond quickly to changing trophic conditions.

Recent outbreaks of gelatinous zooplankton around the world have led to speculation that human activities may have changed the trophic structure of coastal waters, causing jellyfish populations to increase (Legović 1987). For example, Newell (1988) documents the dramatic decline of oysters Crassostrea virginica in Chesapeake Bay since about 1880, and he argues that the phytoplankton they would have consumed may now go instead to zooplankton grazers, thus providing additional food to zooplanktivores such as medusae, and consequently enlarging their populations. A model by Ulanowicz \& Tuttle (1992) predicts an $89 \%$ reduction in gelatinous zooplankton if oysters were restored to their former abundance in Chesapeake Bay. Reductions of zooplanktivorous fish populations due to commercial harvesting also could result in enhanced zooplankton foods for jellyfish (Mills 1995. Purcell et al. 1999). Increased nutrients from sewage effluents or fertilizers in estuarine or coastal waters may change plankton food webs in ways such that jellyfish populations increase (Parsons et al. 1977); however, direct evidence connecting human effects on estuarine systems with changes in jellyfish populations is lacking. For example, no data on the abundances of Chrysaora quinquecirrha medusae exist before 1960, a 
time by which Chesapeake Bay was already badly impacted, and medusa numbers have not generally increased since then (Cargo \& King 1990). The lack of historical data on environmental variables, nutrients, and plankton populations prevents adequate evaluation of possible effects of fisheries and eutrophication an jellyfish population sizes.

\section{Field sampling}

The dramatic differences in the numbers of Chrysaora quinquecirrha medusae during July 1995 and 1996 in Chesapeake Bay are consistent with our experimental results. Medusae were 2 orders of magnitude more abundant in 1995, when all 3 factors that we found to increase ephyra production (salinity, temperature, and food) were greater than in 1996. The fact that medusae occurred at the same salinities in 1995 and 1996 , but at temperatures that differed by $3.5^{\circ} \mathrm{C}$, suggests that salinity constrained medusa distribution but that temperature did not.

It is more difficult to evaluate the relative importance of zooplankton abundance on population size of Chrysaora quinquecirrha in situ because of trophic interactions throughout the food web. Production in the Chesapeake system is strongly linked to nutrient inputs brought by springtime freshwater flow from the Susquehanna River, which supplies $60 \%$ of the freshwater and $80 \%$ of the nitrogen to the upper bay (Malone et al. 1988, Harding \& Perry 1997). In years of high river flow, like 1996, allochthanous nutrient input is high, leading to high phytoplankton and zooplankton biomasses, as seen in April 1996 (Boynton et al. 1997). By summer, the system is strongly stratified, and phytoplankton production depends on nutrient recycling above the pycnocline. Because of the high springtime nutrient input, high zooplankton densities might have been expected in July 1996, but that was not observed. July zooplankton densities may have been low due to predation by the ctenophore Mnemiopsis leidyi, which occurred in high densities (maximum $52 \mathrm{~m}^{-3}$ ) throughout Chesapeake Bay in July 1996 (Purcell \& Houde unpubl. data). We could not evaluate the possible effects of the different sampling methods used in 1995 and 1996 on the measured zooplankton densities.

Few studies document the causes of interannual variation in medusa population size. Food availability generally is invoked to explain population variation in scyphomedusae, as for Aurelia aurita (e.g. Schneider \& Behrends 1994); however, other factors may be equally important. Hernroth \& Gröndahl (1985) attributed a 2 orders of magnitude difference in the number of $A$. aurita ephyrae during 2 years to predation on the scyphistomae by a nudibranch in 1 year. In the northern Adriatic Sea, outbreaks of Pelagia noctiluca are initiated by enhaced water advection from the south, bringing the medusae into the northern region, where warmer than normal winters and water temperatures sustain a continuous population of the medusae, which ususally cannot overwinter there (Purcell et al. 1999). Cargo \& King (1990) found that flow from the Susquehanna River (January through June), and water temperature (May) correlated best with July to August medusa numbers at Solomons, Maryland. Lu et al. (1989) showed a similar pattern for the edible scyphozoan Rhopilema esculenta, for which strobilation and survival decreased below $14 \%$ and above $20 \%$ salinity, and dramatic reductions of medusae in situ were linked to high river flow. Here, we have shown that environmental variables (temperature, salinity, and food) affect the production of ephyrae in laboratory experiments and population size in situ. Therefore, evidence is accumulating that a combination of hydrographic and environmental factors often are responsible for medusa population outbreaks.

Acknowledgements. This research was funded by grants from NSF (OCE-9019404 and OCE-9633607) and from the University of Maryland Sea Grant College (UMSGC)(R/P-98P/D) to J.E.P. We thank Dr D. Meritt for use of the oyster dredge, Dr D. Jacobs for statistical advice, and REU student B. Byne (funded by NSF grant OCE-930001 to the UMSGC) for her valuable assistance. Logistical support and environmental data were supplied by the TIES Group at UMCES (NSF grant DEB-9412113). We especially thank Dr E. D. Houde's group for assistance in the field, Dr M. R. Roman's group for use of 1996 zooplankton data, and C. Pacey and M. Kiladis for field data analysis and figure preparation. UMCES Contribution No. 3121

\section{LITERATURE CITED}

Baird D. Ulanowicz RE (1989) The seasonal dynamics of the Chesapeake Bay ecosystem. Ecol Monogr 59:329-364

Black RE, Webb KL (1973) Metabolism of 1311 in relation to strobilation in Chrysaora quinquecirrha (Scyphozoa). Comp Biochem Physiol 45A:1023

Boynton WR, Boicourt W, Brandt S, Hagy J, Harding L, Houde E, Holliday DV, Jech M, Kemp WM, Lascara C, Leach SD, Madden AP, Roman M, Sanford L, Smith EM (1997) Interactions between physics and biology in the estuarine turbidity maximum (ETM) of Chesapeake Bay, USA. ICES CM1997/S: 11

Brewer RH, Feingold JS (1991) The effect of temperature on the benthic stages of Cyanea (Cnidaria: Scyphozoa), and their seasonal distribution in the Niantic River estuary, Connecticut. J Exp Mar Biol Ecol 152:49-60

Calder DR (1974) Strobilation of the sea nettle, Chrysaora quinquecirrha, under field conditions. Biol Bull 146: 326-334

Cargo DG, King DR (1990) Forecasting the abundance of the sea nettle, Chrysaora quinquecirrha, in the Chesapeake Bay. Estuaries 13:486-491 
Cargo DG, Rabenold GE (1980) Observations on the asexua reproductive activities of the sessile stages of the sea netthe Chrysaora quinquecirha (Scyphozoa). Estuaries 3 $20-27$

Cargo DG, Schultz LP (1966) Notes on the biology of the sea nettle, Chrysaora quinquecirrha, in Chesapeake Bay Chesapeake Sci 7:95-100

Cargo DG, Schultz LP (1967) Further observations on the biology of the sea nettle and jellyfishes in the Chesapeake Bay. Chesapeake Sci 8:209-220

Chen JK, Ding BW, Liu CY (1985) Effect of nutritional conditions on the strobilation of edible medusa, Rhopilema esculenta Kishinouye. J Fish China/Shuichan xuebao 9 $321-329$

Cones HN Jr, Haven DS (1969) Distribution of Chrysaora quinquecirrha in the York River. Chesapeake Sci 10: $75-84$

Cowan JH Jr, Houde ED (1993) Relative predation potentials of scyphomedusae, ctenophores and planktivorous fish on ichthyoplankton in Chesapeake Bay. Mar Ecol Prog Ser 95:55-65

Dumont HJ (1994) The distribution and ecology of the freshand brackish-water medusae of the world. Hydrobiologia 272:1-12

Gatz A.J Jr, Kennedy VS, Mihursky JA (1973) Effects of temperature on activity and mortality of the scyphozoan medusa, Chrysaora quinquecirrha. Chesapeake Sci 14: $171-180$

Gröndahl R, Hernroth L (1987) Release and growth of Cyanea capillata (L.) ephyrae in the Gullmar Fjord, western Sweden. J Exp Mar Biol Ecol 106:91-101

Harding LW Jr, Perry ES (1997) Long-term increase of phytoplankton biomass in Chesapeake Bay, 1950-1994. Mar Ecol Prog Ser 157:39-52

Hernroth L, Grondahl R (1983) On the biology of Aurelia aurita (L.): 1. Release and growth of Aurelia aurita (L.) ephyrae in the Gullmar Fjord, western Sweden, 1982-83. Ophelia 22:189-199

Hernroth L, Gröndahl R (1985) On the biology of Aurelia aurita (L.): 2. Major factors regulating the occurrence of ephyrae and young medusae in the Gullmar Fjord, western Sweden. Bull Mar Sci 37:567-576

Hofmann DK, Neumann R, Henne K (1978) Strobilation, budding and initiation of scyphistoma morphogenesis in the rhizostome Cassiopea andromeda (Cnidaria: Scyphozoa). Mar Biol 47:161-176

Hofmann DK, Fitt WK, Fleck J (1996) Checkpoints in the life-cycle of Cassiopea spp.: control of metagenesis and metamorphosis in a tropical jellyfish. Int J Devel Biol 40: 331

Kikinger R (1992) Cotylorhiza tuberculata (Cnidaria: Scyphozoa) - Life history of a stationary population. PSZN I: Mar Ecol 13:333-362

Kramp P (1961) Synopsis of the medusae of the world. J Mar Biol Assoc UK 40:1-469

Legović T (1987) A recent increase in jellyfish populations: a predator-prey model and its implications. Ecol Model 38 $243-256$

Loeb MJ (1972) Strobilation in the Chesapeake Bay sea nettle Chrysaora quinquecirrha 1 The effects of environmental temperature changes on strobilation and growth. J Exp Zool 180:279-292

Lu N, Liu C, Guo P (1989) Effect of salinity on larva of edible medusae Rhopilema esculenta Kishinouye) at different development phases and a review on the cause of jellyfish resources falling greatly in Liaodong Bay. Acta Ecol Sinica $9: 304-309$
Luther GW, Cole H (1988) Iodine speciation in Chesapeake Bay waters. Mar Chem 24:315-325

Malone TC, Crocker LH, Pike SE, Wendler BW (1988) Influences of river flow on the dynamics of phytoplankton production in a partially stratified estuary. Mar Ecol Prog Ser 48:235-249

Mayer AG (1910) Medusae of. the world, Vol III. The scyphomedusae. Carnegie Institution, Washington, DC

Mills CE (1995) Medusae, siphonophores, and ctenophores as planktivorous predators in changing global ecosystems. ICES J Mar Sci 52:575-581

Möller H (1979) Significance of coelenterates in relation to other plankton organisms. Meeresforsch 27:1-18

Newell REI (1988) Ecological changes in Chesapeake Bay: Are they the result of overharvesting the American oyster, Crassostrea virginica? Chesapeake Research Consortium Publ 129:536-546

Olmon JE, Webb KL (1974) Metabolism of 131I in relation to strobilation of Aurelia aurita L. (Scyphozoa). J Exp Mar Biol Ecol 16:113-122

Parsons TR, von Brockel K, Koeller P, Takahashi M (1977) The distribution of organic carbon in a marine planktonic food web following nutrient enrichment. J Exp Mar Biol Ecol 26:235-247

Purcell JE (1992) Effects of predation by the scyphomedusan Chrysaora quinquecirrha on zooplankton populations in Chesapeake Bay. Mar. Ecol Prog Ser 87:65-76

Purcell JE, White JR, Roman MR (1994a) Predation by gelatinous zooplankton and resource limitation as potential controls of Acartia tonsa copepod populations in Chesapeake Bay. Limnol Oceanogr 39:263-278

Purcell JE, Nemazie DA, Dorsey SE, Houde ED, Gamble JC (1994b) Predation mortality of bay anchovy Anchoa mitchilli eggs and larvae due to scyphomedusae and ctenophores in Chesapeake Bay. Mar Ecol Prog Ser 114: $47-58$

Purcell JE, Malej A, Benović A (1999) Potential links of jellyfish to eutrophication and fisheries. Coastal Estuarine Stud 55:241-263

Schneider G, Behrends G (1994) Population dynamics and the trophic role of Aurelia aurita medusae in the Kiel Bight and western Baltic. ICES J Mar Sci 51:359-367

Silverstone M. Galton VA, Ingbar SH (1978) Observations concerning the metabolism of iodine by polyps of Aurelia aurita. Gen Com Endocrinol 34:132-140

Spangenberg DB (1967) Iodine induction of metamorphosis in Aurelia. J Exp Zool 165:441

Spangenberg DB (1968) Recent studies of strobilation in jellyfish. Oceanogr Mar Biol Annu Rev 6:231-247

Spangenberg DB (1.971) Thyroxine induced metamorphosis in Aurelia. J Exp Zool 178:183-194

Thiel H (1962) Untersuchungen uber die Strobilisation von Aurelia aurita L. an einer Population der Kieler Forde. Kieler Meeresforsch 18:198-230

Ulanowicz RE, Tuttle JH (1992) The trophic consequences of oyster stock rehabilitation in Chesapeake Bay. Estuaries 15:298-306

UNEP (1991) Jellyfish blooms in the Mediterranean. Proceed. ings of II Workshop on Jellyfish in the Mediterranean Sea Mediterranean Action Plan Technical Reports Series 47 United Nations Environment Programme, Athens

Wright DA, Purcell JE (1997) Effect of salinity on ionic shifts in mesohaline scyphomedusae, Chrysaora quinquecirrha. Biol Bull 192:332-339

Yasuda T (1970) Ecological studies on the jellyfish Aurelia aurita, in Urazako Bay, Fukui Prefecture. 1 Occurrence pattern of the medusa. Bull Jpn Soc Ser Fish 35:1-6

Submitted: July 3, 1998; Accepted: November 3, 1998

Proofs received from author(s): April 6, 1999 